\title{
Surfaces
}

\section{The Expanded Body and the Fragmented Body: Inside and Beyond Narrative}

\section{Maria Pandolfi}

Volume 2, 1992

ACTES DU COLLOQUE « REPENSER LA CULTURE »

ACTS OF THE CONFERENCE "RETHINKING CULTURE"

URI : https://id.erudit.org/iderudit/1065231ar

DOI : https://doi.org/10.7202/1065231ar

Aller au sommaire du numéro

Éditeur(s)

Les Presses de l’Université de Montréal

ISSN

1188-2492 (imprimé)

1200-5320 (numérique)

Découvrir la revue

Citer ce document

Pandolfi, M. (1992). The Expanded Body and the Fragmented Body: Inside and Beyond Narrative. Surfaces, 2. https://doi.org/10.7202/1065231ar
Résumé de l'article

Une réflexion sur l'anthropologie à partir de Gramsci et de sa théorie sur la résistance, réflexion mettant l'accent sur l'exemple de la sorcellerie en Italie.
Copyright (C) Maria Pandolfi, 1992

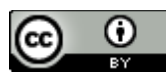

Ce document est protégé par la loi sur le droit d'auteur. L'utilisation des services d'Érudit (y compris la reproduction) est assujettie à sa politique d'utilisation que vous pouvez consulter en ligne.

https://apropos.erudit.org/fr/usagers/politique-dutilisation/ 


\title{
CONFERENCE PROCEEDINGS
}

\section{"RETHINKING CULTURE"}

The Expanded Body and the Fragmented Body: Inside and Beyond Narrative $<$

Maria Pandolfi

This paper was originally delivered at the conference Rethinking Culture held at the University of Montreal, April 3-5, 1992. The organizers would like to thank the following sponsors for their financial support:

\section{Social Science Research Council of Canada}

Faculty of Arts and Sciences, University of Montreal

Vice Rector for Teaching and Research, University of Montreal

Department of Comparative Literature, University of Montreal

\author{
Alitalia
}

\section{ABSTRACT}

A rethinking of anthropology in terms of Gramsci's account of resistance with special focus on the example of witchcraft in Italy. 


\section{RÉSUMÉ}

Une réflexion sur l'anthropologie à partir de Gramsci et de sa théorie sur la résistance, réflexion mettant l'accent sur l'exemple de la sorcellerie en Italie

\section{The body as communication, the body as resistance}

In recent years anthropology has viewed the body as a particular locus of agency, where external or internalized forces exercise their coercive power, at the same time producing different forms of resistance. Many authors have allowed for more complex readings of the corporeal and for the body to become the other. And they have freed it from the configuration that made it the locus par excellence of social communication via Bourdieu, totally internal to power strategies or via Foucault, or the locus of the internalization of social norms, the theatricalization of any process of civilization via Elias. Indeed, the body has been used to demonstrate, for example, the contradictory aspects for human experience, problematizing the subject, who is articulated on a host of fronts and in a multiplicity of actions.

A notion that has shown a particular sensitivity to the reading of all the possible languages of the body as retranscriptions of social strategies is that of resistance. This is an ambiguous notion and one that has been mediated in the United States chiefly through the writing of Foucault and in Italy through the writing of Gramsci. This notion is increasingly used also in medical anthropology, and it allows me now to make a critical reading of some aspects of Italian tradition of Gramscian anthropology.

\section{Historicity, narrativity}

The present work is divided into two distinct parts. The first is a consideration of possession in Southern Italy and a critical review of the anthropology of E. De Martino, the Italian Gramscian ethnologist, which moves between the historicist-idealist tradition, the Gramscian view of 
Italian peasant reality, and the ontological-existential radicality of subjective experience.

The second part offers my own field material as a reading that, while it does not provide answers, critically traverses between the Italian Gramscian perspective and North American phenomenological experiential readings and explores not only forms of resistance, but the ways in which orbits of subjective independence retranscribe and renegotiate partial or implicit social strategies.

If anthropological work can also be legitimized via individual and social fractures where (if they ever existed) continuity, congruence, and symbolic equivalence seem to have vanished or operate according to other rules, the aim of the present paper is to work on particular forms of renegotiating subjective experience and social strategies at a time when the continuity of the narrative of history has broken off, that narration of History via Vico, Hegel, and Croce to which Italy's anthropology, highly conditioned by historicism and Gramsci, has accustomed us. My research material demonstrates an amputation of memory consequent of the amputation on historical continuity in the possession rituals in the Sannio area where I have been conducting research for the past decade.

My reflections are critical of Italian anthropological tradition, which has constrained articulation of single social histories into the History of confrontation between the hegemonic and the subaltern cultures in which any subjective and corporeal form of resistance is treated as mechanical, implicit, and unconscious and in which the idea of a subject in crisis is relegated to a "meta-historical" zone, a crease in history where active subjects are flattened out and cancelled. At the same time I treat with caution some readings which attribute great force of action and independence to opposition and resistance: here possession, illness, and somatization are read as privileged loci of social change for the individual.

\section{De Martino via Croce and Gramsci: resistance without subjectivity, resistance without History}

In his 1959 notes on tarantism in Apulia, De Martino found that the Christian form resembled the pagan one in the therapeutic magic used in 
this kind of possession, which was once very widespread in the Apulian region of Italy. "The features of tarantism in Apulia in the second half of the seventeenth century are sufficiently clear", he noted. "The crisis was marked by a state of deep melancholic depression or stupor, and the way the person fell to the ground was hysteroid in nature." De Martino extended his interest elsewhere in the Mediterranean (for instance to the Islamic countries) in search of types of possession that were comparable to Apulian kind, especially in terms of treatment and the relationship of music and dance, and traced them all the way back to Plato's corybants. De Martino's concluded that the tarantism of Apulia deserved careful religio-historical analysis both of the pagan sources and of the Christian reabsorption fostered by the preaching of the Jesuits.

Then De Martino considered the aggregation of meaning that these possession rituals had for the individual and for subaltern culture, which he considered against the background of a peasant south that was disaggregate and not uniform. He read it, among other things, in the framework of an attempt, by way of Gramsci, to legitimize every expression of popular cultures as usually an implicit response to the risk facing an oppressed class of losing itself in the quotidian. So it was a controversial question that mobilized de Martino's successors in Italy, or rather Marxist anthropologists, in regard to Gramsci's observations on folklore, a position that authorized the view that any form of resistance is some how implicit, mechanical, unconsciously ritualized, and reproduced in a mechanical fashion. While it offers protection, it also precludes the possibility of self-awareness and choice, because it arises from the condition of being subaltern. It is "a passive experience" then, if such a term is permissible, in which the Heideggerian dasein -- a notion that De Martino both loved and hated, a notion that is central to the historicist-ontological articulation of the individual, hegemonic culture, and subaltern cultures -- is contrained by the ideology of class. De Martino continued to insist on the need for religiohistoric reconstruction ranging throughout the Mediterranean area and throughout the history, and he was to legitimize such rituals as tarantism and death as life forms of subaltern classes that have endured for centuries, existing in pagan times and reelaborated within the Catholic religion.

It has been hard to consider the ritual of possession in Italy without taking account of De Martino's theoretical and methodological stance. The human body that first in the fields, then at home, and even in church throws itself to the ground, screams, has convulsions, and feels as if it had been bitten by a tarantula is simultaneously inscribed and interpreted at two levels: in a religious-historical perspective via an age-old Mediterranean tradition; and in a Marxist vein to legitimize a subterranean contractual force, the construction of a subaltern identity via rituals that are inscribed in a perspective of contraposition to the official world. 
In this latter view, possession takes the form of a locus of resistance, for while possession threatens the individual with loss of his own identity, it also offers the protection created by the subaltern culture. In this view, there seem to be two different levels of resistance. At one level every form of folklore, and this includes possession, becomes a form of a resistance to the cultural assimilation brought by any official hegemonic organization. Thus, for example, according to De Martino, resistance in Southern Italy is not against centralized political power but against assimilation by the Catholic Church.

The other level, more subjective, which is what interests us more particularly at the present symposium, is the body as the locus of resistance. Here too, although not explicitly, De Martino would seem to suggest to use the same notion. The possessed body might be a last locus of aggregation, the locus of redemption from a possible "crisis of presence" caused by the hegemony of other classes. What can a possessed individual possibly do to resist that sense of disaggregation which arises from the social sphere but gets lodged in the individual subject, that risk of a fragmented ego, a psychopathological catastrophe?

Where there is no narrative, Croce said, there is no history. De Martino, qua Crocean and historicist, ascribes a particular procedure of resistance to an ambiguous notion of dehistorification that gives the subject in crisis the possibility of at least provisional escape from quotidian time. Should De Martino consider this procedure a particular form of resistance that allows the self in crisis to protect itself? Is it right to think that a kind of resistance might exist that was not immersed in History with a capital H? By stepping out of History, the subject at risk enters a metahistorical position, a suspended state, one that is implicitly protective. It might be hypothesized that while the idealist historical theoretical stance singles out only the process of history and not that of individual histories, the notion of dehistorification may be a particular form of resistance to social change as well as to psychopathological breakdown. In this way, social relations and subaltern relations are closed off and suspended.

De Martino does not seem concerned, in a Gramscian perspective, to credit different micromechanisms of aggregation of meaning for the individual in crisis. And the body that is possessed, a body that expands and contracts, seems to be a kind of ontological rooting of the experience of human existence, a battlefield where class struggle immobilizes and determines every historical process. Thus in De Martino the notion of passive experience has three epistemological dimensions: 1) as the root of individual subjectivity; 2) as the ontological risk of identity loss; and 3) as emersed in the historico-idealistic process. 
In a circular way this blocks further and more complex analysis of social change. In my opinion, the attention and sensitivity to remodelling subjective identity in De Martino's approach is very strong, but the mechanism of the process of class conflict ultimately blocks other levels of aggregation of meaning that are steeped in the experience of the subject in crisis and subsequently become other loci of communication and social contracting.

It would be interesting and might actually be necessary to go back and consider Gramsci, De Martino and his heirs, and Italian Marxist anthropologist generally, in terms of a reappraisal of the notion of resistance, the kind of thing that seems to be happening in some recent American anthropological work. (I am thinking, among others, of some tendencies in political economy and critical medical anthropology). This perspective too would call for reconsideration of some over-simplified readings of Gramsci and Foucault. But it is not my intention here to face this line of work, which is still in process.

\section{From Acting out to Narrative}

Twenty five years after Gramsci's Observations on folklore and De Martino's work of tarantula possession rituals, I have found that possession functions as a form of renegotiating subjectivity, and any somatization and experience of bodily suffering changes from being an experience that is acted out to an experience that is narrated. These are possessions that are only verbalized, in which one set of social actors, women, that is constructed as if it were physiological but it is in fact genealogical. Any psychosomatic idiom of possession is replaced by iconic use of speech which penetrates and takes its form from experience. These new narrative form, however blocks, closes, and controls every kind of social relations.

I should like to shift now to the situation that developed towards the end of the 1960s. My memories of those times have been subsequently absorbed by the passage of time, and they have been colored by reading and by cinematic fictions about the South of Italy, so I am very cautious about my references to that past. I was a student and I arrived for the first time in the Sannio's area which was to become some twenty years later the field of my research. Nevertheless my memory of one episode has remained crystal clear. 
A young woman is walking slowly across a village square when suddenly she begins wildly shouting, she throws herself to the ground and twists around in a state of hysterical crisis. The rhythm of the writhing body is alternately one of excitement and struggle. It is the rhythm of a custom going back through the ages in places that have long been home to the crisis of possession. I also remember the silence of that nearly empty square. A few people began to arrive very slowly, men, old people, children, and a single peasant. They watched the woman fill the surrounding space with her body. They approached in silence and formed a semicircle around her. They stayed near her and shared the crisis with her, but without undue curiosity. There was neither condemnation nor compassion on the part of the group: the event was sheltered by a semicircle of human beings that shared fully in the event.

I can remember no other details, nor am I altogether sure that the intervening years have not somehow "dramatized" these episodes. Yet the perception of villages with few men, many old people and children, and the crisis of women is all part of a unitary and precise memory which I may have forgotten for years, but it suddenly came back to mind in late 1983, when the boundaries of memory recognized the geographical boundaries of the Sannio area in Campania, the Caudine Valley between the provinces of Avellino and Benevento, as far as the province of Caserta, where the hills and mountains of Campania still seem alive with a parallel and hidden identity that is hard to square with the idea of a homogeneous Southern Italy.

Choosing a first study theme in those parts after a lapse of twenty years was certainly not a neutral action; it would have been hard to forget the work of De Martino. So I decided to go back and study that phenomenon and the changes that had taken place in the wake of emigration from the countryside first and economic growth later.

After some months of work, I realized that in the area of San Marco dei Cavoti and the surrounding villages the possession crisis no longer seemed to exist, or at least it was not available on the social scene to be shared and ritualized. Nevertheless the village of San Marco dei Cavoti has kept its memory clearly alive. As long as Don Virgilio Parisi was parish priest, in the 1960s, there were episodes of group or individual possession. But Don Parisi was also an exorcist, and the local population still acknowledges his role with great respect. The priest who succeeded him, Don Adolfo Giancola, came from outside, from Rome. With the departure of the exorcist priest, every manifestation of possession shared on the social scene disappeared as well. Any transformation of distress or mental suffering was, and is, often remembered and commented on by the inhabitants. And the local doctors point to the almost total disappearance of the classic hysterical symptoms, but they also register a general increase in hypochondriacal states and a 
host of psychosomatic manifestations. By the end of the 1970s absolute silence seems to have fallen on the "shared social scene": psychic pain travelled along more solitary and hidden ways of expression.

So I started wondering how that female distress had been transformed: a distress that had expressed itself for uninterrupted centuries had disappeared. How were women able to share individual pathology and social conflict, disturbances and illness, sufferings that were petrified and plans that were hidden, in that cultural area which had fallen silent vis-à-vis the community?

I pursued possession and failed to find it, but the women gradually led me to it, via the account of their bodies and through an iconic use of speech. Distress was now located inside something that was closed and controlled, a body that was overseen by narrative, where social relations appear totally under control: a shift from possession acted-out to possession that is verbalized. Does the narrative capability of a throbbing or suffering body block and contain all social relations? As resistance, as a possible individual strategy, as another locus of social communication?

Material form some ten years in the field shows very clearly that the focus of narration has changed: there has been a shift from the body possessed that expanded and occupied the whole social scene, a body immersed and contained in history, to a body that is fragmented and experienced only in its telling, a body that in rhetorical construct preserves the rhythm of possession while expressing blockage of communication. The world of women's narrative seems to operate by closing itself off and opposing any form of social organization. Social conflict now more than ever leads women to talk about themselves in terms of defeat and negative events, to assert themselves only through the imaginative world of the physiological, which uses to narrate the subject in checkmate.

My hypothesis is that there exists today an itinerary still to be built linking history with a capital $\mathrm{H}$ to the different forms that social histories may assume, and that different social strategies, strategies that are no longer collective (such as hegemony and the subaltern), exist in nuce precisely through the forms of control and closure implemented by women, but they are still in process and still to be identified.

I slowly began to realize that there was a female discourse transmitted via a female route that recounted the history of the village, economic and social reality, family relations, and the conflicts that pervade social roles. There is a grammar of narrative that is exclusively symptomatic, and if it is interpreted within a single subjective story it appears to be discourse about 
real symptoms, about "real" illness, about real psychic pain. An intense emotional rhythm of pain and bodily suffering permeated each woman's narration, and it seemed keyed to reconstructing or seeking out other lines of communication.

The way the women spoke about history was by weaving an ontological warp of their own independence through the narration of symptoms, illness and emotions built up like an ancestral somatic ritual repeated in different social and individual stories alike. There is constant identification with one's own mother, sister, maternal grandmother, maternal aunt, and so on, but an identification fixed and keyed to a failure: the wish to leave the village, to be able to "act like a man", to transgress family rules. Fantasies about "getting away in order to breathe" are never described as possibi- lities for a woman to find self affirmation nor as things achieved, but only as failed attempts that have left traces inscribed in the body. Almost all the narrations speak of hopes dashed by a "somatic" event: it is the body that weakens, the body that fails to win.

\section{The short-circuiting of action: two ways of narratives}

This kind of communication takes place via a continuous short circuiting of action in two ways. The first is constructed through the phenomenology of the witch who is always present in the narrative of women as strange, different, bizarre, and odd. Here the attempt is made in the face of behavior that is considered transgressive and that seeks to exert social control to consign all that is female to a zone of negative power, thus constraining the female world to renegotiate its own space in society along a parallel path.

The second way, that I call verbalized possession, unfolds through the female line and constructs an account of a single large ill body, a large body whose pieces make up a mosaic of what is female: an individual ethos built on defeat, on the short circuiting of a relationship. On the one hand it is catastrophic identity that penetrates, destroys, cripples, and blocks the social body, in the semblance of a witch. On the other hand it is a failed identity that inscribes in the body, in the form of a memorial, the traces of the impossibility of this route and via a discourse that is ancestral and somatic, it takes on the semblance of woman as a loser. The catastrophe of the witch acts as a destructive force from outside, and the failure of the female line, perceived as a special "genealogy of symptoms" in the maternal line, acts as a destructive force from inside. Narrative about the witch is always "projection", because the witch is otherness, the witch is always elsewhere. Discourse about failure is first-person narrative, or it follows the 
female line of descent, and it is enclosed within the social boundaries of the body.

This iconic use of speech seems then to be a privileged clue for rethinking that is impossible for the sole notion of resistance to contain all the teeming collective history, new subjective histories in progress, and possible strategies of communication, which today are only partial and fragmented. Nor is the notion of resistance sufficient as metahistorical and dehistoricizing action, as De Martino would have it. This kind of narrative steps outside of teeming history and finds its space in the breaks between the social and the private and constructed inner micro-histories, yet steps back into collective history by way of forms that are still to be explored. In other words it means: firstly to leave forever behind History as historicism ( Vico, Hegel, Croce); secondly to rethink these "body-micro-histories" not as subaltern narratives, nor as a subjective and psychological experience, but as transversal, implicit, and central ways of social aggregations. We shall have to look beyond the idea of resistance and understand that these micromechanisms of "body histories" may construct, although they do not yet, a social strategy which is not based any more on narrative.

\section{Mariella Pandolfi}

University of Rome La Sapienza

Surface Page d'Acceuil/Home Page 